UDC 61

\title{
EFFECT OF WORK SAFETY AND OCCUPATIONAL HEALTH (K3) ON TURNOVER INTENTION WITH WORK SATISFACTION AS MEDIATOR VARIABLES: A STUDY ON PT MULIA MEKANIKAL ELEKTRIKAL
}

\author{
Safitri Ide Wahyu, Musadieq Mochammad Al, Aziz Aulia Luqman* \\ Faculty of Administrative Science, University of Brawijaya, Indonesia \\ *E-mail: aulialuqmanaziz@ub.ac.id
}

\begin{abstract}
This research was an explanatory research with quantitative approach. The population and sample of this research were PT Mulia Mekanikal Elektrikal's employees from Technical Division which amounted to 71 employees. The sampling technique of this research was purposive sampling, which took the whole population with certain considerations. The data collection was conducted by distributing questionnaires and documentation. The data analysis method was descriptive statistics analysis and inferential statistics using path analysis with t-test as hypothesis testing. The conclusion from the results of this research exhibits that Work Safety is significantly effect towards Employee's Job Satisfaction with significance value of 0.000 , Occupational Health significantly affect Employee's Job Satisfaction with significance value of 0.000 , Work Safety significantly affect Employee's Turnover Intention with significance value of 0.000 , Occupational Health significantly affect Employee's Turnover Intention with significance value of 0.007 , and Employee's Job Satisfaction significantly effect towards Employee's Turnover Intention with significance value of 0.000
\end{abstract}

\section{KEY WORDS}

Work safety, occupational health, job satisfaction, turnover intention.

Flippo (1984, in Sofyandi, 2008: 182) stated that maintenance function involves protection of physical, mental and employee attitudes/emotions. The existence of OSH program in a company ensures that employees as part of human resources feel preserved and cared for by maintaining their security and health. The government has supported this effort. This effort was expressed by Indonesian Minister of Manpower M. Hanif Dhakiri at the meeting of the ASEAN Labor Ministers Meeting on Occupational Safety and Health at the XXI World Congress on Safety and Health at Work 2017 or known as the ASEAN Ministerial Meeting of Ministers in Safety and Health Work (K3) held in Singapore on 3-8 September 2017. This meeting aims to improve the protection aspect for workers and support Sustainable Economic Growth (SDGs) by 2030 throughout the ASEAN region (source: www.liputan6.com accessed in December 2017).

In addition to the government that supports efforts to implement K3 on the company, K3 became an important study for PT PLN (Persero). It is proven by the PLN Outlook 2017 dialog with the theme of Role and Responsibility of Leader in People Safety conducted at the end of 2017. The stakeholders of electricity, such as vendors, contractors, and the community, were invited to provide input and evaluation in understanding the problems occurred, improve work safety to deter negative impact on PLN (Focus Magazine, 2017: 14). The role of the vendor is very important. Aside from being PLN's partner, vendors are also human resources who directly work in the field to realize PT PLN (Persero) programs. The risk of electrical injuries is very high. Without good security, workplace accidents will often occur.

Occupational Safety and Health Application (K3) is very important to be applied as the main capital in supporting employee job satisfaction, especially on the technical part. Company attention on K3 can ensure employees' happiness and satisfaction at work because they feel safe and can avoid the risk of a work accident. Employees working in the field always interact directly with heavy equipment construction and electrical voltage that 
potentially endanger them and others. There's a high risk involved for employees working in the technical section, therefore it is necessary to have proper application and knowledge in running the technical tools. The use of sophisticated technology such as heavy equipment and modern machines would ensure convenience, but it has a risk of work accident if the use is not in accordance with the proper manner of usage. Should the company gives attention to the safety and security of its employees, it would ensure employees happiness, safety, and comfort while working. Therefore job satisfaction will be achieved by employees.

Luthans (2005: 243) states job satisfaction is a state of happy emotions or positive emotions derived from a job assessment or a person's work experience. Employees may feel satisfied if work and individual aspect support their safety and security as the work involved contains high risk. Should the aforementioned aspects do not support the employees, they would be dissatisfied. Based on the described phenomenon and the attention given by the government and PT PLN, it can be concluded that safety and health are important aspects for companies and its employees. The government issued laws as a form of effort in implementing occupational safety and health programs in anticipation of the risks of accidents, both caused by human and environmental factors. This is necessary in order to provide protection for production sources in an endeavor to improve efficiency, productivity, and job satisfaction.

Job satisfaction is an individual issue because each individual will have different levels of satisfaction in accordance with the values prevailing in each of them. Employees will demonstrate their commitment to remain loyal to the company if job satisfaction is obtained. On the other hand, dissatisfaction will affect the employees' turnover, low attendance (absenteeism) and other negative attitudes. Job dissatisfaction is often identified as one of the reasons for turnover intention.

Lack of attention to labor force leads to a decrease in morale, attitudes, loyalty, as well as an increase in absence and turnover. This results in a lack of achievement of company goals. According to Sedarmayanti (2010: 205), "human resources is a company capital that if not properly maintained can cause harm to the company". One apparent disadvantage is, employees moved to other companies due to job dissatisfaction. It could be concluded from the statement that the success of the company in achieving its objectives is determined by the existence of employees. Therefore a company should always strive to maintain employees' satisfaction, in order for them to remain in the company and perform tasks properly. Maintaining competent employees is a challenge for the company.

According to Harnoto (2002: 2), "Turnover Intentions is the level or intensity of the desire to get out of the company, many of the reasons that led to Turnover Intentions and among them the desire to get a better job". This occurs after the individual has evaluated their respective work or the place of employment. The attitude that arises in the individual is a desire to consider, evaluating the possibility of finding a better job elsewhere. If the opportunity to switch jobs is not available or no attractive vacancies present, would cause low mental and emotional morale. The employee often arrives late, being absent, disregarding surrounding environment, lack of enthusiasm or lack of willingness to work well. High Employee Turnover Intention can have a negative impact for the company because it creates instability against labor conditions, decreased employee productivity, unfavorable working atmosphere, and impact on the loss of time and opportunity to take advantage of opportunities.

Based on the 2018 PLN Outlook dialogue meeting, the authors are interested in researching one of PT PLN's vendors especially in East Java which services are often used, namely PT Mulia Mekanikal Elektrikal. PT Mulia Mekanikal Elektrikal is one of the companies engaged in electrical construction services, low voltage electricity, medium voltage or home connection and electrical installation. Since its establishment, PT Mulia Mekanikal Elektrikal has conducted electricity projects for Government Agencies, SOEs, especially PT. PLN (Persero), starting from Gardu Trafo Tiang (GTT), Medium Voltage Power Network (JTM), Low Voltage Power Network (JTR) and Home Connection (SR). Therefore, the authors examined the Application of Occupational Safety and Health (K3) in PT Mulia Mekanikal Elektrikal as well as its impact on Job Satisfaction and Employee Turnover Intention. 
This electrical installation activity is not an easy task. It takes skill, steadiness, thoroughness, and full concentration during the process. The risk of working accidents is very high. Employees, especially the Technical Division, are directly exposed to high-voltage electricity. Therefore, it is very important for the company to always pay proper attention to Occupational Safety and Health (K3) and ensure the safety and health of its workers, thereby reducing the risk of accidents, improving company productivity, and meeting customer satisfaction.

Based on the description, this study aims to: (1) Describe and explain Work Safety, Occupational Health, Job Satisfaction and Turnover Intention; (2) To determine and explain the significant effect of Work Safety on Employee Satisfaction of PT Mulia ME; (3) To determine and explain the significant effect of Occupational Health on Employee Satisfaction of PT Mulia ME; (4) To determine and explain the significant effect of Work Safety on Employee Intention Turnover of PT Mulia ME; (5) To determine and explain the significant effect of Occupational Health on Employee Intention Turnover of PT Mulia ME; and (6) To determine and explain the significant effect of Employee Satisfaction on Employee Intention Turnover PT Mulia ME.

The results of this study are expected to contribute theoretically to the development of human resource management studies, especially in terms of the linkages between work safety, occupational health, job satisfaction, and turnover intention. In addition, the results of this study can provide valuable input to the company to pay attention to these three variables in the management of the company so that the level of turnover intention can be anticipated early.

\section{LITERATURE REVIEW}

Work Safety. Swasto (2011: 107) described work safety as "Work safety concerning the entire process of labor protection against possible hazards arising in the work environment". Mathis and Jackson (2003: 222) define work safety as a physiologicalphysical and psychological condition of labor resulting from the work environment that the company provides. Mathis and Jackson (2003: 245) added that work safety refers to the protection of a person's physical well-being against work-related injuries. Suma'ur (2009: 104) interpreted the work safety as a series of business to create a safe and peaceful working atmosphere for employees who work in the company concerned.

Occupational Health. Moenir (2006: 207) referred to occupational health as "An effort and circumstances that allow a person to maintain their health condition during work". According to Mondy and Noe (2005: 360), "Occupational health is freedom from physical violence. Health risks are factors in work environments that work beyond the prescribed time period, an environment that can create emotional stress or physical impairment ". Silalahi and Rumondang (2000: 139) stated that occupational health deters diseases that may arise after starting work".

Job Satisfaction. According to Fraser (1985: 43), job satisfaction, or in a more specific sense, employee satisfaction at work, is a difficult definition defined even in the simplest terms. For employees, job satisfaction arises when the perceived benefits of their work go beyond the marginal cost incurred, which the employee considers adequate. However, the satisfaction is not a permanent state, because it can be influenced and changed by forces both inside and outside the work environment. Robbins and Judge (2013: 113) state that job satisfaction is a positive feeling about a job that is the result of evaluation of some characteristics.

Handoko (2001: 193) describes job satisfaction as a pleasant or unpleasant emotional state of employees when judging their work. Job satisfaction reflects one's feelings toward one's work. This is evident in the employee's positive attitude to the job and everything that is faced in the work environment. Dharma (1996: 125) calls job satisfaction a set of employee feelings about the pleasantness or unpleasantness in their work.

Turnover Intention. Turnover Intention is the tendency or intention of employees to stop working from their current work voluntarily (Zeffane, 1994 in Putrianti, 2014: 30). 
According to Sudiro (2011: 152), "employee turnover is the level of movement beyond the membership limit of an organization. In a broad sense, turnover is defined as the flow of employees who enter and exit the company. " Harnoto (2002: 2) described turnover intention as follows:" Turnover Intentions is the level or intensity of the desire to get out of the company, many reasons influence Turnover Intentions and among them is the desire to get a better job".

According to Simamora (2004: 626), there are three indicators that affect Turnover Intention:

- Intention to quit. There is an interest of employees to leave their jobs in the hope of getting a better job.

- Job search. Employees compare jobs that are better than their current job. They consider there would be no future if they keep working in the current organization

- Thinking to quit. Employees who have a desire to move to another organization in the hope that their career can thrive in that place and the possibility of employees switch job in the future.

Hypothesis. Based on the literature review above, the hypothetical model of this study is illustrated in Figure 1.

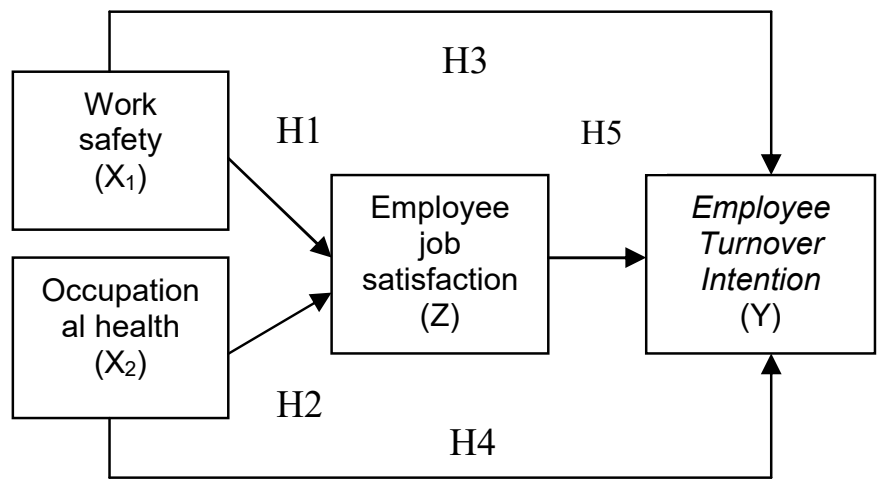

Figure 1 - Hypothesis Model

- $\mathrm{H}_{1}$ : There is a significant effect of Work Safety $\left(\mathrm{X}_{1}\right)$ on Job Satisfaction $(Z)$;

- $\mathrm{H}_{2}$ : There is a significant effect of occupational health $\left(X_{2}\right)$ on Job Satisfaction $(Z)$;

- $\mathrm{H}_{3}$ : There is a significant effect of Work Safety $\left(\mathrm{X}_{1}\right)$ on Employee Turnover Intention $(\mathrm{Y})$;

- $\mathrm{H}_{4}$ : There is a significant effect of Occupational Health $\left(\mathrm{X}_{2}\right)$ on Employee Turnover Intention (Y);

- $\mathrm{H}_{5}$ : There is a significant influence of Job Satisfaction $(Z)$ ) on Employee Intention Turnover $(\mathrm{Y})$.

\section{METHODS OF RESEARCH}

The research method utilized is encyclopedia research with a quantitative environment. The research was conducted at PT Mulia Mekanikal Elektrikal at Griyashanta Housing Block H-112, Mojolangu Regency, Lowokwaru District, Malang City, Indonesia. The company was chosen because PT Mulia Mekanikal Elektrikal is one of the largest vendors and services most widely used by PT PLN (Persero) in Malang area.

Sampling was conducted using purposive sampling method. It is a sampling technique involving the source data with certain considerations. The sample of this research is the employee of the Technical Division. This does not include the employee in the other sectors. The employees working in Technical Division have a high job risk and are directly related to $\mathrm{K} 3$. The primary data of this study were taken from 71 samples who acted as respondents in this study. 
Data collection was conducted by asking respondents to fill out the prepared questionnaire. The questionnaire contains the items used to measure the three variables in this study. Meanwhile, secondary data is taken from books as well as company archives. From the data collection process, 71 pieces of questionnaires from all research samples have returned the questionnaires to the researchers for further data analysis.

The data analysis of this research consists of descriptive analysis and inferential analysis using Path Analysis and t-test.

\section{RESULTS AND DISCUSSION}

The following is the result of primary data analysis consisting of Work Safety Relationship to Job Satisfaction of Employee, Working Health Relationship to Job Satisfaction of Employee, Safety Relationship to Employee Intention Turnover, Occupational health Relationship to Employee Intention Turnover, and Employee Satisfaction Relationship to Employee Turnover Intention

Table 1 - Results of Work safety Coefficient Test on Employee Job Satisfaction

\begin{tabular}{|l|c|c|c|c|c|}
\hline \multicolumn{1}{|c|}{ Independent variable } & Dependent variable & Standardized Coefficients & t count & Sig & Desc \\
\hline Work safety & Employee job satisfaction & 0.477 & 5.459 & 0.000 & Sig \\
\hline R Square $=0.605$ & N =71
\end{tabular}

Source: Processed Primary Data, 2018.

Table 2 - Test Results of Occupational Health Coefficient on Employee Job Satisfaction

\begin{tabular}{|l|c|c|c|c|c|}
\hline \multicolumn{1}{|c|}{ Independent variable } & Dependent variable & Standardized Coefficients & t count & Sig & Desc \\
\hline Occupational health & Employee job satisfaction & 0.424 & 4.860 & 0.000 & Sig \\
\hline R Square $=0.605$ & $\mathrm{~N}=71$ \\
\hline
\end{tabular}

Source: Processed Primary Data, 2018.

Table 3 - Results of Work safety Coefficient Test on Employee Intention Turnover

\begin{tabular}{|l|l|l|c|c|c|}
\hline Independent variable & Dependent variable & Standardized Coefficients & t count & Sig & Desc \\
\hline Work safety & Employee Turnover Intention & -0.269 & -4.111 & 0.000 & Sig \\
\hline R Square $=0.848$ & N =71
\end{tabular}

Source: Processed Primary Data, 2018.

Table 4 - Results of Occupational Health Coefficient Test on Employee Intention Turnover

\begin{tabular}{|l|l|l|l|l|l|}
\hline Independent variable & $\begin{array}{l}\text { Dependent } \\
\text { variable }\end{array}$ & $\begin{array}{l}\text { Standardized } \\
\text { Coefficients }\end{array}$ & t count & Sig & Desc \\
\hline Occupational health & $\begin{array}{l}\text { Employee } \\
\text { Turnover Intention }\end{array}$ & -0.178 & -2.808 & 0.007 & Sig \\
\hline $\begin{array}{l}\mathrm{R} \text { Square }=0.848 \\
\mathrm{~N}=71\end{array}$
\end{tabular}

Source: Processed Primary Data, 2018.

Table 5 - Test Results of Employee Satisfaction Coefficient on Employee Turnover Intention

\begin{tabular}{|l|l|l|l|l|l|}
\hline Independent variable & Dependent variable & Standardized Coefficients & t count & Sig & Desc \\
\hline Employee job satisfaction & Employee Turnover Intention & -0.587 & -7.748 & 0.000 & Sig \\
\hline R Square $=0.848$ & $\mathrm{~N}=71$
\end{tabular}

Source: Processed Primary Data, 2018. 
To determine the indirect effect of work environment variables to work discipline variables can be conducted by multiplying the results of direct influence on the path analysis.

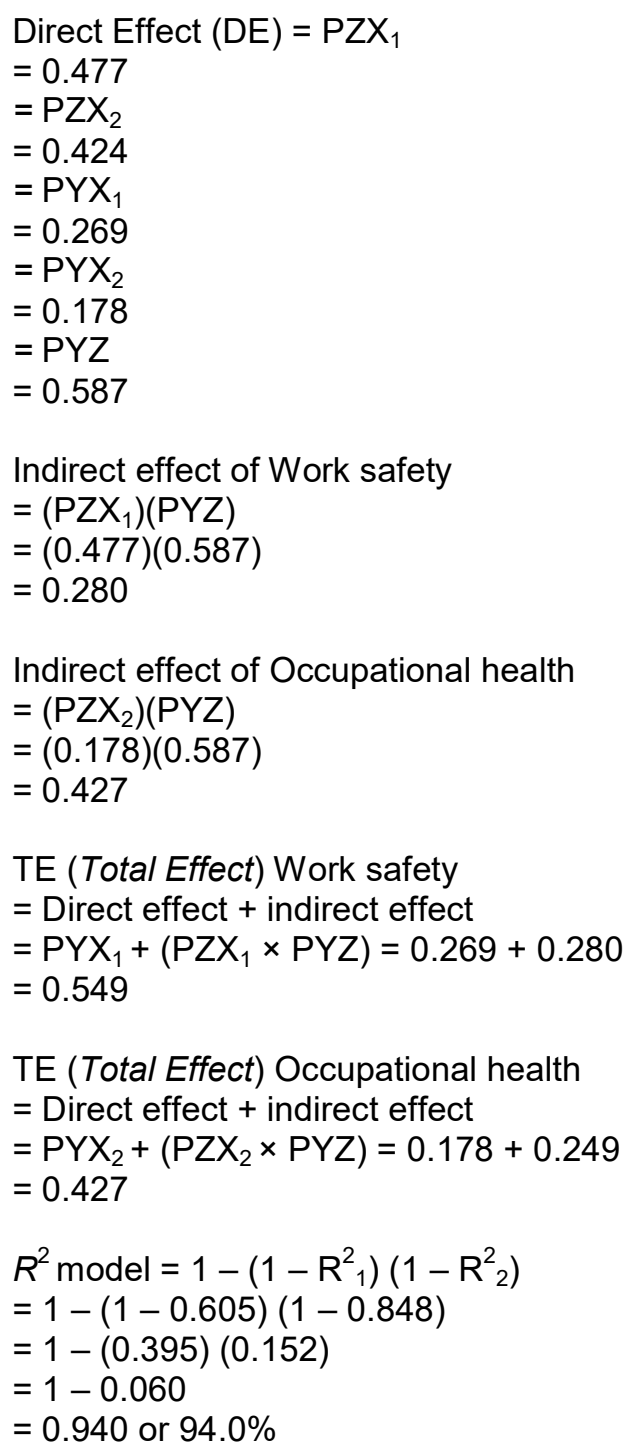

\section{DISCUSSION OF RESULTS}

Work Safety, Occupational Health, Employee Job Satisfaction and Employee Turnover Intention. The Safety Variable $\left(X^{1}\right)$ studied in this research has 7 (seven) statement items covering 3 indicators namely workplace condition, behavior, and psychological mood of the employee. The item with the highest value in this variable is the employee feels not stressed while working. In conclusion, the majority of employees in the Technical Division work comfortably because they feel no pressure, both physically and emotionally in the work environment. This Safety Variable obtains a grand mean of 4.43 from the answer of the Technical Division PT Mulia ME. The value is categorized very well. Therefore based on the engineering sector employee's point of view, the application of Safety in the company is very good.

Occupational Health Variable $\left(X^{2}\right)$ studied in this research has 8 (eight) statement items covering 3 indicators such as medical work environment, worker health facility, and health care workforce. The item with the highest value in this variable is the company provides clean bathroom facilities. The majority of employees of the Technical Division considers the company's bathroom facility clean. This Occupational Health Variable obtains a grand mean of 4.16 from PT Mulia ME Technical Division employee questionnaire answer. 
This value falls into the good category. Therefore the application of Occupational Health at the company is good.

Employee Satisfaction Variable (Z) studied in this research have 8 (eight) statement items covering 2 indicators such as the satisfaction of working condition and job satisfaction. The items with the highest value in this variable indicate the Employees are satisfied with the safety procedures that have been established in the company. It can be concluded the majority of Technical Division considers that safety procedures set by the company are very satisfactory. This Job Satisfaction Variable earns a grand mean of 4.23 from PT Mulia ME Technical Division employee questionnaire answer. The scores are in very good categories. Therefore the employees are satisfied with the Safety and Health (K3) implementation in their company.

The Employee Turnover Intention $(\mathrm{Y})$ variables studied in this research have 5 (five) statement items covering 3 indicators: Intention to quit, Job search, Thinking to Quit. The item with the lowest value in this variable is Employees want to move to another company in the hope of building a career in another company. In conclusion, the majority of the engineering employees stated that they do not want to move and build careers in other companies. Turnover Intention Variable obtained a grand mean of 1.81 from PT Mulia ME Technical Division employee questionnaire answer. The acquisition of these values falls into a very bad category. It indicates that the employees have no intention of leaving their current company.

Path Analysis Result Overview (Path Analysis). This study aims to examine the influence between Work Safety $\left(X_{1}\right)$ to Employee Satisfaction variable $(Z)$. The path analysis results exhibit a significance value of 0.000 . It proves that $H_{1}$ was accepted that there is a significant influence between the variables of Work Safety (X1) to Employee Satisfaction variable $(Z)$. The effect of these two variables can be seen from the mean value of the interrelated items in each variable. In the Work Safety variable $\left(X_{1}\right)$ the item with the highest mean value is the employee feels not depressed while working. This is evidenced by the lack of work accidents that occurred in PT Mulia ME. Before starting work, the chief executive of the Technical Division warms up and briefs to make employees relax while working. The state of a volatile and depressed soul is very dangerous for the workers themselves and the environment. Employees who feel comfortable when working, tend to focus to minimize work accidents due to human error (negligence caused by the negligence of human). Employee Satisfaction ( $Z$ ) variable items with the highest mean value are employees are satisfied with the safety procedures set by the company. Employees who weren't depressed while working feel satisfied while working. One method to ensure employees are not depressed while working is to apply good safety procedures to minimize work accidents due to human error. The results of the research on the influence of these two variables are in line with the research conducted by Wardana (2014) which states Work Safety has a significant effect on Job Satisfaction.

Then, the results of the occupational health path analysis show a significance value of 0.000 . It proves that $\mathrm{H}_{2}$ is accepted that there is significant influence between occupational health variable $\left(X_{2}\right)$ to employee job satisfaction variable $(Z)$. The effect of these two variables can be seen from the mean value of the interrelated items in each variable. In the variable Occupational Health $\left(\mathrm{X}_{2}\right)$ items with the highest mean value of the company provided clean bathroom facilities. This is evidenced by the clean bathroom in PT Mulia ME. The main office of PT Mulia ME is located in Griyashanta Housing area which is a large house. The purpose of the president director of PT Mulia ME is to make the employees work as comfortable as possible at home. Existing bathroom facilities are made with a modern touch. Employee Satisfaction variable $(Z)$ items exhibit that the employees are satisfied with the sanitation system (clean water and bathroom facilities). It obtained a mean value of 4.24 which is included in the very good category. The employee considers sanitation system is very important because the dirty bathroom in a company will easily transmit the disease among employees. Dirty water cannot be consumed or used because it can cause various diseases inside and outside the body. 
From the statement that has been described, it can be concluded that companies who pay attention to the sanitary system will guarantee the health of its employees from various diseases. Therefore it ensures pleasure and satisfaction during work because employees are being maintained by the company. The result of the research on the influence of these two variables is in line with the research conducted by Wardana (2014) who stated that the Occupational health has a significant effect on the Job Satisfaction.

On the other hand, the test results of the influence between the variables of Work Safety $\left(X_{1}\right)$ to Employee Intention Turnover variable $(Y)$ shows a significance value of 0.000 . It proves that $\mathrm{H}_{3}$ was accepted that there is a significant influence between the variables of Work Safety $(\mathrm{X} 1)$ to Employee Intention Turnover $(\mathrm{Y})$ variables. The effect of these two variables can be seen from the mean value of the interrelated items in each variable. In the Work Safety variable $\left(X_{1}\right)$, one item with a high mean value is an employee feels safe working using Personal Protective Equipment (APD). Personal Protective Equipment (APD) is one of the safety devices that support the safety of employees while working to avoid the risk of work accidents. According to Mondy and Noe (2005: 360), work safety is the protection of employees from injuries caused by work-related accidents.

Employee Turnover Intention $(Y)$ variable items with the lowest mean value are employees want to move to another company in the hope of building a career in another company. So from the statement that has been described can be concluded, the employees who feel safe working by using Personal Protective Equipment will feel comfortable and peaceful at work. They would feel protected and cared for by the company, the desire to move to another company will be reduced. The results of the research on the influence of these two variables are in line with (Utama et al., 2015) research which states that job security is an important aspect to ensure that the employees who feel safe and not threatened in work will enjoy high job satisfaction. They would be less likely to move to another company.

The influence of the variable Occupational Health $\left(X_{2}\right)$ on the variable Employee Turnover Intention $(Z)$, the path analysis results show a significance value of 0.007 . It proves that $\mathrm{H}_{4}$ is accepted that there is significant influence between Occupational Health variable $\left(\mathrm{X}_{2}\right)$ to Employee Intention Turnover variable $(\mathrm{Y})$. The effect of these two variables can be seen from the mean value of the interrelated items in each variable. In the Occupational Health variable (X2), items with the highest mean value are the company provide clean bathroom facilities. This is evidenced by the clean bathroom in PT Mulia ME. The main office of PT Mulia ME is located in Griyashanta housing which is a large house. The purpose of the president director of PT Mulia ME is to make the employees work as comfortable as possible at home. Existing bathroom facilities are made with a modern touch. Employees Turnover Intention $(Y)$ variable items 'employees think to resign from current workplace' has a mean value of 1.72 that fall into the bad category. Based on the perspective of employees, sanitation system is very important. The dirty bathroom in a company will easily transmit the disease among employees of its users. Dirty water cannot be consumed or used because it can cause various diseases inside and outside the body.

From the statement that has been described, it can be concluded that companies paying attention to the sanitary system will guarantee the health of its employees from various diseases. It would ensure employee comfort. The employees would consider their health is guaranteed by the company. Therefore the desire to move or quit the current job is low.

The influence between Employee Satisfaction variable $(Z)$ to Employee Intention Turnover $(\mathrm{Y})$ variable, the path analysis result show significance value equal to 0.000 . It proves that $\mathrm{H}_{5}$ is accepted that there is significant influence between Employee Satisfaction variable $(Z)$ against Employee Intention Turnover $(Y)$ variable. The effect of these two variables can be seen from the mean value of the interrelated items in each variable. On employee job satisfaction variable (Z), the highest mean value is the employee feel satisfied with work safety procedure which has been determined by the company. It obtained a mean value equal to 4,32 which is in the very good category. This is evidenced by the lack of work accidents that occurred in PT Mulia ME. Therefore, Safety and Health (K3) is a top priority in 
PT Mulia Mekanikal Elektrikal Malang. PT Mulia ME is one of the companies that provide electrical construction services. Working in the field of services with a job that has a high accident potential work, safety is a top priority of the company to deter negative impact for PT Mulia ME partners. If the company does not provide safety and health insurance to employees, then employees will feel dissatisfied resulting in decreased productivity of the company. It is important for the company to give job satisfaction to its employees.

Employee Turnover Intention ( $Y$ ) items with the lowest mean value are the employees want to move to another company in the hope of building a career in another company. It could be concluded that employees who are satisfied with safety procedures established company do not have the desire to move to another company in the hope of building a career in another company. Broadly speaking, employees who are satisfied with their current job will not have the desire to move to another company. The results of the research on the influence of these two variables are consistent with the research conducted by Khan and Aleem (2014), Syahronica (2014), and Nanda (2015) which states that Job Satisfaction has a significant negative influence on Turnover Intention.

\section{CONCLUSION}

Based on the research results, there are several conclusions which are described as follows:

- Work Safety $\left(X_{1}\right)$ has a significant positive effect on employee job satisfaction $(Z)$. The direction of a positive relationship indicates that better Work Safety would improve Employee Satisfaction (Z).

- Occupational Health $\left(X_{2}\right)$ has a significant positive effect on employee job satisfaction $(Z)$. The direction of a positive relationship indicates better Health Work $\left(X_{2}\right)$ would improve Employee Satisfaction (Z).

- Work Safety $\left(X_{1}\right)$ and Occupational Health $\left(X_{2}\right)$ have a significant negative effect on Employee Turnover Intention (Y). The direction of negative relationship indicates that better Work Safety $\left(X_{1}\right)$ and Occupational Health $\left(X_{2}\right)$ would decrease Employee Intention Turnover $(\mathrm{Y})$.

- Employee Satisfaction (Z) has a significant negative effect on Employee Turnover Intention $(Y)$. The direction of a negative relationship indicates better Employee Satisfaction (Z) would decrease Employee Turnover Intention (Y).

\section{SUGGESTIONS}

Based on the results of research, this research can provide some suggestions for improvement for the company, which is described as follows:

- Companies need to improve supervision on the use of safety procedures to their employees. Because on the questionnaire items 'employees work in accordance with safety procedures that have been established by the company', many employees stated their hesitance in performing such work. It is important that the safety SOP is adhered to, as the risks of accidents are very high.

- Companies need to improve air circulation system in the company. It is necessary to provide adequate ventilation so that the air circulation in the workspace is good to deter stuffy air and hot atmosphere. Based on item 'Good air circulation in the workplace', there are still some employees declare disagree and doubt.

\section{REFERENCES}

1. Dharma, A. (1996).Manajemen Prestasi Kerja (1st Ed). Jakarta: Rajawali.

2. Fraser, T. M. (1985). Stres \& Kepuasan Kerja. Jakarta: PT. Pustaka Binaprint Pressindo.

3. Handoko, H. T. (2001). Manajemen Personalia dan Sumber Daya Manusia. Yogyakarta: BPFE. 
4. Harnoto. (2002). Manajemen Sumber Daya Manusia. Jakarta: PT. Prehallindo.

5. Jackson, R. L., \& Mathis, J. H. (2002). Manajemen Sumber Daya Manusia. Jakarta: Salemba Empat.

6. (2003). Human Resource Management. New York: Thompson.

7. Khan, A. H., \& Muhammad, A. (2014). Impact of job satisfaction on employee turnover: An empirical study of Autonomous Medical Institutions of Pakistan. Journal of International Studies, 7(1), 122-132.

8. Luthans. (2005). Perilaku Organisasi. Yogyakarta: ANDI.

9. Majalah Fokus PLN. (2017). Meningkatkan Work safety. Desember, pp 14-15.

10. Moenir. (2006). Manajemen Pelayanan Umum di Indonesia. Jakarta: Bumi Aksara

11. Mondy, R. W. (2008). Manajemen Sumber Daya Manusia. Jakarta: Erlangga.

12. Mondy., \& Noe. (2005). Human Resource Management. Jakarta: PT Bumi Aksara.

13. Nanda, N. L. N. K. (2015). Pengaruh konflik kerja-keluarga dan Kepuasan Kerja terhadap Turnover Intention. E-Jurnal Manajemen Unud, 4(9), 2461-2477.

14. Putrianti, A. D. (2014). Pengaruh Kompensasi dan Motivasi Kerja Terhadap Turnover Intention (Unpublished Thesis). Universitas Brawijaya, Malang.

15. Robbins, S. (1996). Perilaku Organisasi. Konsep, Kontroversi, Aplikasi. Translated by Hadyana, P. Jakarta: PT. Prenhallindo.

16. Robbins, S. P., \& Judge, T. A. (2013). Organizational Behavior (15th Ed). New Jersey: Pearson Education

17. Sedarmayanti. (2010). Manajemen Sumber Daya Manusia, Reformasi Birokrasi, dan Manajemen Pegawai Negeri Sipil. Bandung : PT Refika Aditama.

18. Silalahi, B. N. B., \& Rumondang, B. S. (1995).Manajemen Keselamatan dan Occupational health. Jakarta: PT Pustaka Binaman Pressindo.

19. Simamora, H. (2004). Manajemen Sumber Daya Manusia. Yogyakarta: STIE.

20. Sofyandi, H. (2008). Manajemen Sumber Daya Manusia. Yogyakarta: Graha Ilmu.

21. Sudiro, A. (2011). Perencenaan Sumber Daya Manusia. Malang : UB Press.

22. Suma'mur. (2009). Higiene Perusahaan dan Work safety. Jakarta: CV Sagung Seto.

23. Swasto, B. (2011). Manajemen Sumber Daya Manusia. Malang: UB Press.

24. Syahronica, G. (2014). Pengaruh Kepuasan Kerja dan Stres Kerja Terhadap Turnover Intention (Studi Pada Karyawan Departemen Dunia Fantasi PT Pembangunan Jaya Ancol) (Unpublished Thesis). Universitas Brawijaya, Malang.

25. Utama, I. W. M., et al. (2015). Pengaruh Keamanan Kerja pada Turnover Intention dengan Kepuasan Kerja sebagai Variabel Pemediasi. Matrik : Jurnal Manajemen, Strategi Bisnis dan Kewirausahaan, [S.I.], Feb. 2015. ISSN 2302-8890. Available at: $<$ https://ojs.unud.ac.id/index.php/jmbk/article/view/14398>. Date accessed: 17 December 2017.

26. Wardana, R. (2014). Pengaruh Keselamatan dan Occupational health Terhadap Kepuasan Kerja dan Motivasi Kerja (Studi pada Karyawan PT PLN (Persero) Area Malang) (Unpiblished Thesis). Universitas Brawijaya, Malang. 